\title{
Consumo de drogas, opinião pública e moralidade Motivações e argumentos baseados em uso'
}

\author{
Gustavo Venturi
}

\author{
Let's get stupid! \\ AMUNKA DAVILA (1983)
}

\begin{abstract}
Pôr-se em seu lugar, também, é localizar-se, cada um, diante do arrogante: instalar-se na cidadania como um corpo cujo tempo não é devorado pelo trabalho imposto como castigo, e cujo espaço não é ordenado como instituição produzida por elementos alheios à autonomia de cada um de dispor de seu próprio corpo. HERBERT DANIEL (1991)
\end{abstract}

Introdução

O consumo de drogas psicoativas é um fenômeno social tão polêmico quanto antigo e complexo. Alimenta controvérsias na opinião pública e contrapõe políticas que, internacionalmente, variam hoje da regulamentação de sua produção e distribuição pelo Estado para fins recreativos - a exemplo da maconha no Uruguai, desde o governo de José $\mathrm{Mujica}^{2}$ - ao assassinato extrajudicial em massa de "viciados" e traficantes, a exemplo das Filipinas, sob o terror do atual governo de Rodrigo Duterte ${ }^{3}$.

1. "Maconha: (argumentos) baseados em uso" foi título de artigo publicado em 1986 no jornal de campanha a deputado estadual pelo PT do então professor do Departamento de Ciências Sociais da usP, Eder Sader (1941-1988). Intitulado Ovelha Negra, com quatro números ao longo da campanha, o jornal era editado por Maria Célia Paoli (também professora do DCS), Antonio Galves (professor do IME-USP), Sara Muller (artista plástica) e, à época, três alunos de graduação, Marco Antonio de Almeida, Caio Magri e eu. A matéria discutia a descriminalização da maconha com base nos resultados de pesquisa feita com os alunos do curso de ciências sociais (62\% tinham experimentado, 36\% eram usuários), em trabalho da disciplina de Métodos e Técnicas de Pesquisa II, ministrada por Sedi Hirano.

2. Aprovada pelo parlamento em dezembro de 2013, a lei uruguaia permite aos maiores de 18 anos o cultivo doméstico de até seis plantas de cannabis, o cultivo em cooperativas com quinze a 45 sócios (com um máximo de 99 plantas) e a venda em farmácias autorizadas de até quarenta gramas ao mês para cada consumidor registrado.

3. Em seis meses do governo de Rodrigo Duterte, eleito em maio de 2016 com a promessa de erradicar o comércio ilegal, "segundo dados da própria polícia nacional (PNP), já são 6214 as vítimas 'comuns' - pe- 
No Brasil completamos uma década marcada pela ambiguidade da vigente Lei de Drogas: aparentemente avançada e liberal - extinguiu a pena de prisão para o porte e para o cultivo de plantas destinadas ao preparo de drogas ilícitas, desde que "para consumo pessoal" -, a lei n. 11343 , de 2006, tem sido apontada como responsável, na prática, por mais que duplicar a população carcerária do país condenada por delito ligado a drogas (Campos, 2015a; Venturi, 2016), ao deixar à discricionariedade de delegados e juízes a distinção entre porte para uso próprio ou para tráfico ${ }^{4}$. E fechamos o politicamente traumático ano de $2016 \mathrm{com}$ uma espantosa declaração do controverso ministro da Justiça, Alexandre de Moraes (PSDB), de que pretende "erradicar o comércio e o uso de maconha no país" flagrante consonância com a política de enfrentamento da questão conhecida como "guerra às drogas" - vertente ainda hegemônica globalmente, a despeito de todas as evidências de seu fracasso, passado quase meio século de sua enunciação pelo estadunidense Richard Nixon.

Consumir drogas ilícitas é, por definição, um comportamento desviante. Decorrente da categoria de ilegais, em que ora algumas, ora outras substâncias psicoativas são classificadas em cada cultura, época e sociedade, o consumo de drogas acaba por se constituir em um problema social cuja gravidade extrapola em muito os efeitos nocivos potenciais de seu uso abusivo, tendendo a mobilizar uma ampla rede de instituições locais encarregadas de seu controle. De fato, com a divisão arbitrária e simplória de uma gama variada de substâncias psicoativas em drogas lícitas e ilícitas - sugerindo que algumas são mais nocivas, devendo permanecer proibidas; outras, se não benéficas, são menos nocivas, podendo ser toleradas -, a política vigente no Brasil tem produzido um conjunto de efeitos socialmente deletérios. No plano da saúde, bloqueia discussões públicas qualificadas e a difusão de informações sobre as características de cada substância - seus efeitos específicos sobre as atividades do sistema nervoso central, seu potencial para o desenvolvimento de tolerância e de dependência, suas doses letais etc. -, favorecendo práticas de uso abusivo e irresponsável das drogas ilegais (Escohotado, 1997; Macrae e Simões, 2003). Estas, longe de serem minimizadas, agravam-se combinadas ao consumo de álcool, por sua vez tolerado - no que tange à liberação de publicidade, incentivando seu

quenos usuários e traficantes [...]. Do total, 2165 foram mortas pelas forças policiais e 4049 , por grupos de extermínio - os chamados vigilantes" (Sousa Pinto, 2016).

4. Ver $₫ 2^{\circ}$ do artigo 28 da lei n. 11343/06: "Para determinar se a droga destinava-se a consumo pessoal, o juiz atenderá à natureza e à quantidade da substância apreendida, ao local e às condições em que se desenvolveu a ação, às circunstâncias sociais e pessoais, bem como à conduta e aos antecedentes do agente".

5. Ver relato de reunião com representantes de instituições civis convidados pelo ministro para conhecer o conteúdo do Plano Nacional de Segurança, em elaboração pelo governo de Michel Temer (PMDB): "Ministro da Justiça quer erradicar comércio e uso de maconha no Brasil", 2016. 
consumo, e à falta de fiscalização de sua venda para menores de idade - para muito além do razoável.

Ao mesmo tempo, no plano da assim chamada segurança pública, a divisão e a classificação aleatória das substâncias em lícitas e ilícitas sugerem a eventuais usuários de drogas ilegais que uma vez ultrapassada a linha da legalidade, com o consumo de um cigarro de maconha que seja, já se passou para o lado do crime - percepção que tende a ser reforçada e confirmada no contexto de ilegalismos que cerca o seu comércio, como simples decorrência de sua proscrição à categoria de atividade criminosa, e com o tratamento que o sistema de justiça criminal e seus agentes têm dispensado para os consumidores de drogas ilícitas, sobretudo se pobres e pretos, cujo efeito mais evidente tem emergido de forma dramática na superlotação e nos massacres recorrentes que atestam o colapso do sistema prisional brasileiro.

Nesse contexto, a investigação do consumo de drogas exige desde logo que o fenômeno seja abordado ao menos por dois ângulos: o dos usuários de drogas ilícitas - seus interesses e motivações para insistirem em contrariar as leis - e o dos “impositores de regras", os representantes do sistema de justiça criminal ${ }^{6}$, responsáveis pelo cumprimento das leis (Becker, 2008). Se considerados ainda a dimensão global e o montante de recursos que a economia das drogas ilícitas movimenta, não só como mercadoria (nos processos de produção, na distribuição e no consumo), mas também como "justificativa” para a constituição e a manutenção de vastos aparatos de controle social e repressão (Pizano, 2013) - ou seja, levando-se em conta a dimensão de poder que outra vez a própria ilegalidade alimenta (Velho, 1994) -, há ainda duas outras perspectivas a serem incluídas para uma análise abrangente do fenômeno do consumo de drogas ilícitas: a das elites que direta ou indiretamente se beneficiam com a proibição vigente - da indústria bélica ao crime organizado, com suas respectivas redes de apoio nos legislativos, executivos e judiciários mundo afora - e a das populações socialmente mais vulneráveis que, mesmo entre a maioria não usuária, sofrem as consequências de tal política repressiva, essencialmente colonialista e classista, etária e racialmente seletiva ${ }^{7}$.

Com base nos dados de um survey representativo da população brasileira adulta, feito em novembro de $2013^{8}$, este artigo foca a primeira dessas quatro perspectivas,

6. Sobre a perspectiva dos operadores do sistema de justiça criminal, ver Jesus (2011).

7. Em 2011 foram assassinados no Brasil 136,8\% mais negros que brancos. Entre jovens essa taxa foi ainda maior: morreram em homicídios $158,6 \%$ mais negros que brancos, já relativizadas as proporções desses segmentos raciais. Em números absolutos, em 2011 foram assassinados 6540 jovens brancos e 20852 jovens negros, Ver Waiselfisz (2014). Sobre a relação entre o contexto de criminalização das drogas e assassinato de jovens negros no Brasil, ver Venturi (2016). Sobre o crescimento e o perfil etário e racial da população carcerária no estado de São Paulo, ver Campos (2015b).

8. Pesquisa realizada sob a coordenação do Núcleo de Opinião Pública da Fundação Perseu Abramo (FPA), 
qual seja, a dos consumidores de drogas ilícitas, analisando o que aqueles/as que assumem tê-las experimentado, ou mesmo consumi-las com regularidade, têm a dizer para justificar seu comportamento desviante, e confronta as opiniões de usuários e não usuários de drogas sobre a política proibicionista vigente no Brasil. Se é esperado que usuários de drogas sejam mais favoráveis à descriminalização de seu consumo e que não usuários sejam menos favoráveis à mudança das regras, o problema sociológico escolhido aqui para análise está em decifrar o enigma (Lemieux, 2015) encarnado por outros dois segmentos da opinião pública: trata-se de compreender o posicionamento do grupo de não usuários antiproibicionistas, ou seja, contrários à atual política, e o da parcela da população que, embora usuária de drogas ilícitas, é favorável à manutenção da criminalização do consumo.

A hipótese principal trabalhada - fundamentada na teoria construtivista do desenvolvimento moral, elaborada pelo psicólogo-social estadunidense Lawrence Kohlberg (1927-1987) e equipe, a partir das pesquisas seminais do epistemólogo suíço Jean Piaget (1896-1980) - é a de que os posicionamentos em que convergem comportamentos e atitudes aparentemente contraditórios (não usuários favoráveis a legalizar o ilícito e usuários que condenam o próprio comportamento) decorrem de perspectivas sociomorais distintas: a primeira, necessariamente pós-convencional, atitude que tende a ser assumida apenas pelos que conseguem julgar criticamente a lei com base em um ponto de vista moral descentrado e autônomo; a segunda, expressão das perspectivas convencional ou pré-convencional - a convencional, entre autônoma e heterônoma, típica dos que tendem a tomar o legal sempre como o correto ou justo, de modo que, caso ajam contra a regra, o farão com culpa ou arrependimento; a pré-convencional, assumida por quem, a partir de um ponto de vista moral egocêntrico e heterônomo, admite agir contra a regra desde que consiga burlar quem tem por função zelar por sua correta observância e punir os que a transgridem (Piaget, [1932] 1977; Kohlberg 1981, 1984; Colby e Kohlberg, 1987).

\section{Consumo de drogas: comportamentos e motivações}

Dois surveys nacionais anteriores ao dos dados aqui analisados já tinham evidenciado o forte estigma que incide sobre os consumidores de drogas ilícitas no Brasil: em

\footnotetext{
em parceria com a Fundação Rosa Luxemburgo (RLS). Amostragem probabilística nos primeiros estágios (sorteio dos municípios, setores censitários, quarteirões e domicílios), com controle de cotas de sexo e idade (Censo 2010, IBGE) para a seleção final dos indivíduos. Coleta de 2400 entrevistas, em abordagem domiciliar, com aplicação de questionário estruturado em entrevistas face a face, distribuídas em 240 setores censitários, nas áreas urbanas e rurais de 120 municípios, distribuídos pelas cinco macrorregiões do país. Principais resultados publicados em Bokany (2015).
} 
ambos, com amostras independentes e separadas por cinco anos entre a coleta de uma e outra, a categoria "usuários de drogas" liderou com folga - junto com a de “gente que não acredita em Deus", e com surpreendente estabilidade - um ranking de aversão da opinião pública ( $41 \%$ na soma de sente repulsa ou ódio e antipatia), entre 24 grupos/categorias sociais sugeridos em 2003 e 28 grupos sugeridos em $2008^{9}$. No survey aqui em foco, a permanência da associação entre droga e problema social em 2013 foi confirmada logo em uma das primeiras perguntas: diante do enunciado “quando ouve a palavra 'droga', qual é a primeira coisa que você pensa?", quase em sua totalidade as respostas espontâneas dos indivíduos a essa questão aberta expressaram associações indesejáveis, como destruição, ruina, degradação pessoal (15\%) ou familiar (14\%), coisa ruim ou errada (12\%), coisa que mata ou morte (9\%), violência ou crime, bandidagem (8\%), vicio, dependência ou viagem sem volta (6\%), entre muitas outras negativas mencionadas em menor monta. Apenas cerca de um em cada vinte entrevistados fez uma referência "neutra", citando alguma droga (maconha 2\%, álcool ou cachaça, crack, cocaína $1 \%$ cada) e só $1 \%$ fez alguma associação positiva, remetendo o termo a uso recreativo ou à autonomia dos indivíduos para decidir sobre seu consumo.

A negatividade que envolve o significado do termo "droga" na sociedade brasileira contemporânea e o estigma que atinge os consumidores já nos obrigariam, portanto, a tomar as taxas de uso reportadas pela pesquisa como inferiores aos usos efetivamente praticados (quão inferiores é indeterminável). Some-se a isso o cálculo de risco para a confissão de um ato ilegal, no contexto de uma abordagem domiciliar, em que pesem os cuidados tomados para minimizar tal problema, seja na interação com as pessoas entrevistadas, seja na elaboração do questionário ${ }^{10}$. De qualquer forma, a existência e a grandeza desse delta entre as práticas real e aferida

9. Ver Racismo no Brasil (Santos e Silva, 2005) e Diversidade sexual e homofobia no Brasil (Venturi e Bokany, 2011), disponíveis em csbh.fpabramo.org.br. Em patamar abaixo, com cerca de $25 \%$ de aversão, em ambas as pesquisas seguiram as categorias de grupos relacionados com as sexualidades: as identidades LGBT, prostitutas e garotos de programa.

10. A equipe de campo foi orientada a entrevistar as pessoas sozinhas, sem outro residente do domicílio por perto, e ao serem convidadas a participar da pesquisa as pessoas eram informadas sobre a garantia de sigilo de suas identidades e sobre a possibilidade de não responderem qualquer pergunta se quisessem, sem necessidade de justificativa. No que tange ao questionário, as questões usadas para aferir experiências de consumo de drogas ilícitas, feitas já no terço final da entrevista (o que pressupõe alguma diminuição do estranhamento que tende a se estabelecer no início), foram antecedidas por perguntas sobre conhecimento de usuários de uma lista de substâncias e sobre se estas já lhes teriam sido oferecidas, de modo a provocar uma aproximação gradual com eventual confissão de uso. A seguir se perguntou aos entrevistados, "sempre lembrando que as suas respostas não vão ser identificadas", se já tinham "experimentado alguma vez na vida" cada uma das drogas listadas, aferindo-se a frequência do consumo e a idade da iniciação somente ao final, apenas entre os que confirmaram as terem provado. 
do consumo de drogas ilícitas são pouco relevantes para a questão aqui tratada, visto que o objeto em foco não está centrado no tamanho da população que consome drogas, e sim nas motivações, nos argumentos e no perfil social dos que assumem usá-las, comparados aos que declaram que não usam drogas ${ }^{11}$. O alerta para essa diferença entre uso praticado e declarado é sobretudo para que eventuais leitores pouco familiarizados com os limites de um survey não tomem pelo valor de face os resultados descritos a seguir.

Afirmaram já ter experimentado ao menos uma droga ilícita entre quinze substâncias listadas $13 \%$ dos indivíduos da amostra ${ }^{12}$, com destaque para a maconha (12\%), seguida pela cocaína (5\%). As demais drogas proibidas não passaram de $2 \%$ das menções ${ }^{13}$. A taxa de usuários declarados (Tabela 1) é maior entre os homens (19\%) que entre as mulheres (8\%), cai gradualmente com a idade (de $21 \%$ entre os jovens de 16 a 24 anos a $3 \%$ entre os idosos com 60 anos e mais) e cresce com a escolaridade (de 6\% no Fundamental i para $17 \%$ no Superior); é maior entre desempregados (20\%) e os que estão na força de trabalho informal (17\%) que entre donas de casa (7\%) e aposentados (3\%); é maior também entre residentes em área urbana (14\%) que entre residentes no meio rural $(8 \%)$ e no estrato com renda mensal per capita intermediário, de mais de um a dois salários mínimos (20\%, contra $11 \%$ no estrato com renda menor e $14 \%$ no de renda superior). Por fim, a taxa de usuários declarados de ilícitas é maior entre espíritas (16\%) e sobretudo entre os que afirmam acreditar

11. É verdade que, se fossem captados os argumentos e os perfis dos consumidores de drogas não confessos, os resultados gerais sobre as razões e o perfil dos que consomem drogas poderiam ser diferentes dos encontrados apenas entre os consumidores confessos. Mas isso vale para qualquer investigação: os elementos não observados em qualquer pesquisa ou experimento - aquilo que os instrumentos e as técnicas utilizadas não permitem captar - não têm como fazer parte de seu resultado explícito, mesmo que (ou até por sua ausência) possam interferir nos achados.

12. Disseram ter consumido pelo menos uma das drogas listadas, uma ou mais vezes, nos trinta dias que antecederam a respectiva entrevista, apenas $3 \%$ - a rigor um indicador mais preciso do que se poderia considerar como "usuários de drogas". Mas por se tratar de uma base de entrevistas muito reduzida, serão usados na análise - e adiante designados por "usuários" - todos que afirmaram já terem experimentado. É plausível, aliás, que parte dos que experimentaram - ainda que, de novo, o tamanho dessa "parte" seja imponderável - seja de fato usuária regular ou eventual, mas pelas razões expostas não se tenha sentido segura ou confortável para admiti-lo.

13. Crack, lança-perfume, cola ou outro solvente $2 \%$ cada; haxixe, LSD e êxtase em torno de $1 \%$ cada; cogumelos (psilocibina), heroína e morfina cerca de $0,5 \%$ cada. As menos apontadas foram lírio branco ou zabumba (quatro casos) e ópio (um caso). Peiote (mescalina) não teve nenhuma menção. Excluíram-se do cálculo da taxa de $13 \%$ dos que provaram alguma droga ilícita outras quatro substâncias que constavam da lista: anfetaminas ou moderadores de apetite (1\%) e calmantes ou ansiolíticos (1\%), pela impossibilidade de saber se foram usadas para fins terapêuticos, com prescrição médica, ou para fins recreativos ou abusivos; ayahuasca $(0,5 \%)$, porque pode ter sido tomado em cerimônias religiosas do Santo Daime e da União do Vegetal, portanto a princípio com finalidade distinta à do fenômeno aqui focado, e os anabolizantes (2\%) por não serem psicoativos. 
em Deus mas não seguem uma religião (30\%) que a observada entre evangélicos e católicos não praticantes (13\% em cada) ou praticantes $(6 \%)^{14}$.

Em relação às drogas legalizadas, afirmaram nunca terem fumado tabaco $65 \%$ dos indivíduos da amostra, declararam-se ex-fumantes $18 \%$ e fumantes à época da pesquisa $17 \%$; contra $42 \%$ que se declararam usuários de bebidas alcoólicas, 19\% ex-bebedores e 39\% que nunca teriam tomado álcool. Apresentam as maiores taxas de uso corrente tanto de tabaco como de álcool (ver Tabela 1) os homens (respectivamente $21 \%$ e $51 \%$, contra $14 \%$ e $35 \%$ das mulheres) e os sem religião ( $28 \%$ e $57 \%$ ) e espíritas (29\% e 51\%) - os evangélicos as menores (10\% e 19\%). Por idade, o maior grupo de fumantes está entre 40 e 59 anos (21\%) e o de usuários de álcool entre 25 e 39 anos (50\%), enquanto os que menos fumam são os jovens de 16 a 24 anos (13\%) e que menos bebem são os idosos, a partir dos 60 anos (26\%). O tabaco tem mais uso entre os desempregados ou os ocupados no mercado informal (20\% cada) e entre os que não passaram do Fundamental I (22\%); já o álcool tem mais uso entre os que chegaram ao Ensino Superior (52\%, contra 29\% entre os que não ultrapassaram o Fundamental I) e entre os que estão no mercado formal ( $50 \%$, contra $29 \%$ na média dos que estão fora da força de trabalho - donas de casa, aposentados e os que só estudam). Considerando-se a renda per capita, os usuários de tabaco e de álcool tendem a crescer com a renda, mas (como nas ilícitas) têm seu pico no estrato intermediário, de mais de um a dois salários mínimos (tabaco 21\%, álcool 55\%).

A taxa dos que declaram já terem consumido ilícita(s) varia consideravelmente segundo o comportamento relativo ao uso das drogas legalizadas: sendo $13 \%$ na média nacional da população investigada, chega a 33\% entre os que ao mesmo tempo tomam bebidas alcoólicas e fumam tabaco (que correspondem a $13 \%$ da amostra), cai para menos da metade, $15 \%$, entre os que fazem ou já fizeram apenas um ou outro (que são a maioria, $54 \%$ da amostra) e diminui significativamente, para $3 \%$, entre os que dizem nunca terem fumado ou bebido (grupo que corresponde a $33 \%$ dos respondentes). Por fim, considerando uma variável de contexto, a taxa dos que experimentaram droga(s) é maior entre os ( $9 \%$ da amostra) que têm na família "usuário regular" de alguma ilícita (22\%), sobretudo entre os (outros 9\%) que convivem com usuário de ilícita e também com familiar dependente de álcool (27\%), caindo entre aqueles (16\% da amostra) que têm na família apenas usuário de álcool (15\%) ou entre a maioria (66\% da amostra) que não têm usuário regular de ilícita nem abusivo de álcool (10\%) no domicílio.

14. Diferenças estatisticamente significantes ( $p<0,001$ no teste qui-quadrado de Pearson) em todos esses casos. Não apresentaram diferenças as comparações por raça/cor e por residência em região metropolitana ou capital versus municípios do interior. 


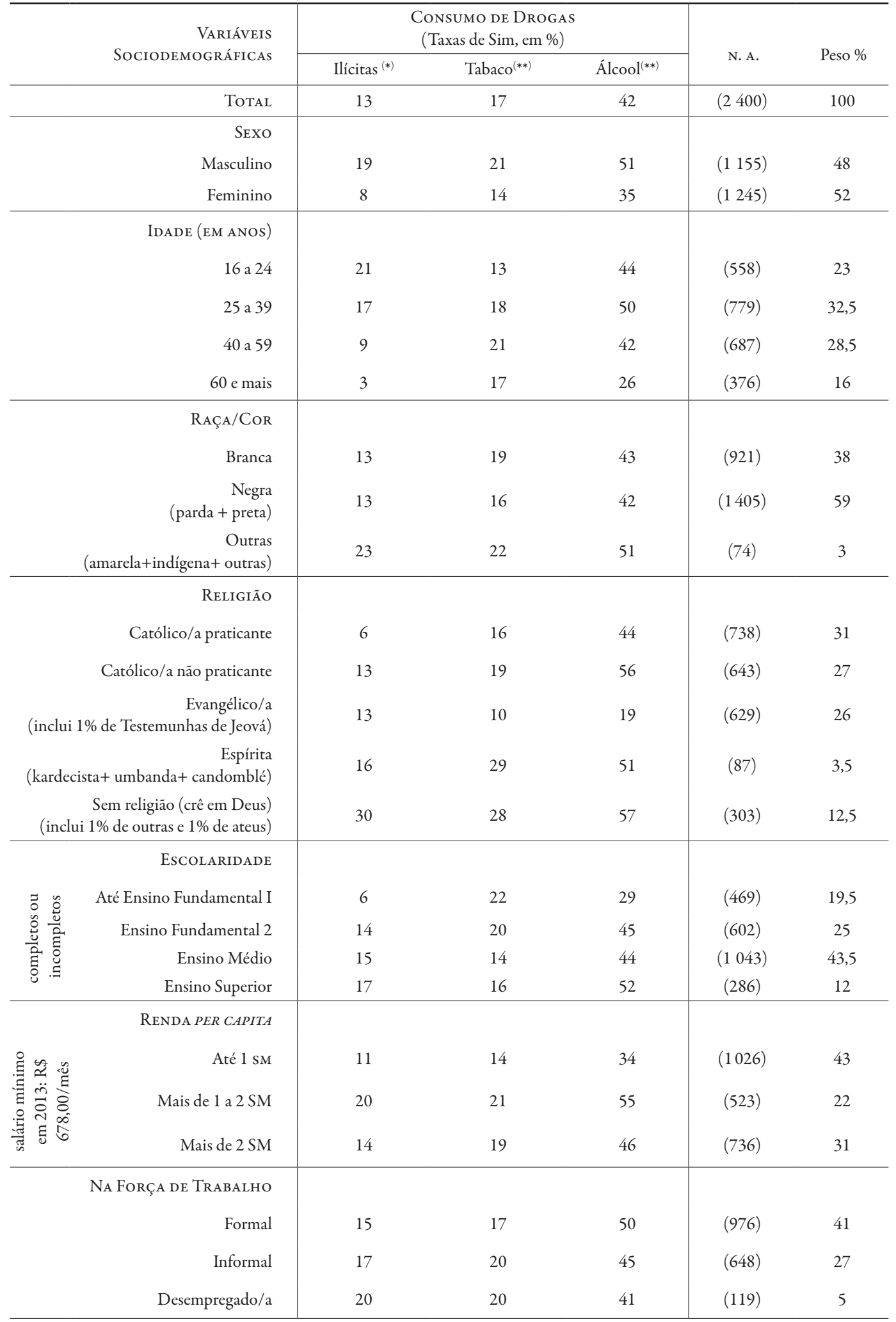




\begin{tabular}{|c|c|c|c|c|c|}
\hline \multirow{2}{*}{$\begin{array}{r}\text { VARIÁVEIS } \\
\text { SOCIODEMOGRÁFICAS }\end{array}$} & \multicolumn{3}{|c|}{$\begin{array}{l}\text { Consumo de Drogas } \\
\text { (Taxas de Sim, em \%) }\end{array}$} & \multirow{2}{*}{ N. A. } & \multirow[b]{2}{*}{ Peso $\%$} \\
\hline & Ilícitas ${ }^{(*)}$ & Tabaco $^{(* *)}$ & Álcool ${ }^{(* *)}$ & & \\
\hline \multicolumn{6}{|l|}{ Fora da ForÇa de Trabalho } \\
\hline Estudante & 12 & 4 & 25 & $(144)$ & 6 \\
\hline Dona de casa & 7 & 14 & 29 & $(215)$ & 9 \\
\hline Aposentado/a & 3 & 18 & 29 & $(298)$ & 12 \\
\hline \multicolumn{6}{|l|}{ LocalizaÇÃo Município } \\
\hline Região metropolitana/capital & 15 & 19 & 44 & $\left(\begin{array}{lll}1 & 139\end{array}\right)$ & 47,5 \\
\hline Interior & 12 & 16 & 41 & (1 261) & 52,5 \\
\hline \multicolumn{6}{|l|}{ ÁREA DE RESIDÊNCIA } \\
\hline Urbana & 14 & 18 & 43 & $(2063)$ & 86 \\
\hline Rural & 8 & 15 & 40 & $(337)$ & 14 \\
\hline
\end{tabular}

(*) "Experimentaram ao menos uma vez" uma ou mais substâncias das seguintes categorias: (1) estimulantes do sistema nervoso central (SNC) - cocaína ou crack; (2) depressoras do SNC - lança-perfume, loló, cola ou outro solvente, heroína, morfina ou ópio; (3) perturbadoras do SNC: maconha, haxixe, LSD, êxtase, cogumelo (psilocibina), peiote ou san pedro (mescalina), lírio branco ou zabumba. Sobre a classificação de psicoativos nesses três grupos, ver Cebrid (2010); ${ }^{(* *)}$ "Consome atualmente".

Fonte: Pesquisa Drogas no Brasil - FPA/RLs (Bokani, 2015). Elaboração própria, com base em banco de dados da pesquisa, disponível no Consórcio de Informações Sociais (CIs) (www.cis.org.br).

Considerando-se álcool, tabaco e ilícitas em conjunto, os grupos distribuem-se nas seguintes proporções (Tabela 2): os $87 \%$ que não provaram ilícitas somam $32 \%$ que nunca consumiram nem álcool nem tabaco, 29\% que bebem ou fumam, $17 \%$ que bebiam e/ou fumavam mas pararam e $8 \%$ que bebem e fumam; os $13 \%$ usuários de ilícitas somam $4 \%$ que também bebem e fumam, $5 \%$ que bebem ou fumam, 3\% que bebiam e/ou fumavam e apenas 1\% que nunca bebeu nem fumou.

Considerando os extremos, se na média nacional $4 \%$ fumam tabaco, tomam bebidas alcoólicas e já usaram droga(s) ilícita(s), essa taxa chega a 6\% dos homens (contra 2\% das mulheres), a $6 \%$ dos jovens de 16 a 24 anos e adultos de 25 a 39 anos (caindo até 0,5\% entre os idosos, com 60 anos e mais), a 7\% dos que chegaram ao Ensino Médio ou adiante (contra $0,5 \%$ dos que não passaram do Fundamental I), a $7 \%$ no estrato de renda per capita intermediário (contra 3\% no de renda mais baixa), a $8 \%$ entre desempregados/as (contra $0,5 \%$ entre aposentados/as), a $12 \%$ entre os sem religião e a $7 \%$ entre os espíritas (contra 2\% entre católicos praticantes ou evangélicos) e a 9\% entre os que convivem na família com outro(s) usuário(s) regular(es) de ilícita, ou com usuário de ilícita e também algum dependente químico de álcool (contra 3\% entre os que não convivem nem com um nem com outro, ou apenas com usuário abusivo de álcool). No outro extremo, se na média nacional 32\% nunca usaram droga ilícita, tabaco ou álcool, essa taxa atinge seus picos entre as mulheres (40\%, contra 23\% dos 
TABELA 2

\begin{tabular}{|c|c|c|c|c|c|c|}
\hline \multirow{2}{*}{$\begin{array}{l}\text { Consumo de } \\
\text { ILÍ́CITA }\end{array}$} & \multicolumn{4}{|c|}{ TRAJETÓRIA DE USO DE ÁLCOOL E TABACO } & \multirow[b]{2}{*}{ TOTAL } & \multirow[b]{2}{*}{ N. A. } \\
\hline & $\begin{array}{l}\text { Bebe e } \\
\text { fuma }\end{array}$ & $\begin{array}{c}\text { Bebe ou } \\
\text { fuma }\end{array}$ & $\begin{array}{c}\text { Bebia e/ou } \\
\text { fumava }\end{array}$ & $\begin{array}{l}\text { Nunca bebeu } \\
\text { nem fumou }\end{array}$ & & \\
\hline Qualquer $^{(*)}$ & $4 \%$ & $5 \%$ & $3 \%$ & $1 \%$ & $13 \%$ & (319) \\
\hline Nenhuma & $8 \%$ & $29 \%$ & $17 \%$ & $32 \%$ & $87 \%$ & $(2081)$ \\
\hline TOTAL & $13 \%$ & $35 \%$ & $20 \%$ & $33 \%$ & $100 \%$ & $(2400)$ \\
\hline N. A. & $(300)$ & $(830)$ & $(477)$ & (793) & $(2400)$ & - \\
\hline
\end{tabular}

(*) “Experimentaram ao menos uma vez” uma ou mais substâncias das seguintes categorias: (1) estimulantes do sistema nervoso central (SNC) - cocaína ou crack; (2) depressoras do SNC - lança-perfume, loló, cola ou outro solvente, heroína, morfina ou ópio; (3) perturbadoras do SNC: maconha, haxixe, LSD, êxtase, cogumelo (psilocibina), peiote ou san pedro (mescalina), lírio branco ou zabumba.

Fonte: Pesquisa Drogas no Brasil - FPA/RLS (Bokani, 2015). Elaboração própria, com base em banco de dados da pesquisa, disponível no Consórcio de Informações Sociais (CIs) (www.cis.org.br).

homens), entre os idosos (39\%) e também entre os jovens ( $40 \%$, contra $27 \%$ nos adultos de 25 a 59 anos), entre os com menor renda per capita (40\%), entre desempregados/ as (35\%), donas de casa (41\%) e entre os evangélicos ( $42 \%$, contra $24 \%$ entre espíritas e católicos não praticantes e $23 \%$ entre os sem religião).

Comportamentos à parte, conforme aferido na pesquisa por pergunta aplicada antes que os entrevistados falassem de suas próprias práticas com drogas lícitas e ilícitas, a opinião pública brasileira atribui o uso de drogas majoritariamente a processos de socialização e problemas sociais, por um lado, em combinação, por outro, com fatores que podem ser agrupados como debilidades individuais dos usuários. Em respostas espontâneas e múltiplas, sete em cada dez entrevistados (70\%) apontaram como motivações para o uso de drogas fatores de contexto familiar e social (Tabela 3), puxados por "influência dos amigos / de terceiros" (35\%, $1^{\circ}$ lugar) e "desestruturação familiar" (29\%, 2), além de "falta de religião" (14\%), "facilidade de acesso/fronteiras abertas" (9\%) e "pobreza/desemprego/falta de oportunidade/de educação" (8\%). O segundo bloco, agrupando as "explicações" para o consumo de drogas voltadas mais para os indivíduos, recebeu resposta de quase metade dos entrevistados (48\%), lideradas por "fraqueza de caráter/falta de vergonha/safadeza" (23\%, $3^{\circ}$ mais citado) e "fuga de problemas/de situações difíceis/para ter coragem" $\left(22 \%, 4^{\circ}\right)$, seguidos por “dependência/vício” e problemas psicológicos (12\%).

Ou seja, prevalecem respostas em que transparecem concepções em que o indivíduo usuário de droga é ora vítima da sociedade, ora culpado por causar o que se considera um mal a si mesmo. Menos de dois quintos (38\%) citaram como motivações para as pessoas usarem drogas algum tipo de busca, expressando ainda que implicitamente uma concepção de indivíduo como sujeito em interação ativa com o meio, capaz de fazer escolhas. Agruparam-se nesse bloco "explicações” para o uso 


\begin{tabular}{|c|c|c|c|}
\hline \multirow{2}{*}{ POR QUE CONSUMIR DROGAS? } & \multicolumn{2}{|c|}{ DROGAS JÁ CONSUMIDAS } & \multirow[b]{2}{*}{ TOTAL } \\
\hline & QUALQUER $^{(*)}$ & Nenhuma & \\
\hline SocializaçÃo/Contexto & $63 \%$ & $71 \%$ & $70 \%$ \\
\hline Influência de terceiros/de amigos & $35 \%$ & $35 \%$ & $35 \%$ \\
\hline Desestruturação familiar & $25 \%$ & $30 \%$ & $29 \%$ \\
\hline Falta de religião & $5 \%$ & $15 \%$ & $14 \%$ \\
\hline $\begin{array}{l}\text { Facilidade de acesso/fronteiras abertas/ } \\
\text { impunidade }\end{array}$ & $10 \%$ & $9 \%$ & $9 \%$ \\
\hline $\begin{array}{l}\text { Pobreza/desemprego/falta de oportunidades/ } \\
\text { de educação }\end{array}$ & $4 \%$ & $8 \%$ & $8 \%$ \\
\hline DEBILIDAde Individual & $45 \%$ & $49 \%$ & $48 \%$ \\
\hline Fraqueza de caráter/falta de vergonha/safadeza & $18 \%$ & $23 \%$ & $23 \%$ \\
\hline $\begin{array}{l}\text { Fuga de problemas/enfrentar dificuldades/ } \\
\text { ter coragem }\end{array}$ & $22 \%$ & $22 \%$ & $22 \%$ \\
\hline $\begin{array}{l}\text { Por dependência/vício/problemas psicológi- } \\
\text { cos/dendência genética }\end{array}$ & $10 \%$ & $12 \%$ & $12 \%$ \\
\hline Buscas & $46 \%$ & $37 \%$ & $38 \%$ \\
\hline $\begin{array}{l}\text { Curiosidade/vontade de experimentar/ } \\
\text { por ser proibido }\end{array}$ & $23 \%$ & $20 \%$ & $20 \%$ \\
\hline Busca de prazer/para se divertir & $26 \%$ & $18 \%$ & $19 \%$ \\
\hline $\begin{array}{l}\text { Busca de estímulo/de energia/ } \\
\text { desempenho sexual/no trabalho }\end{array}$ & $6 \%$ & $4 \%$ & $5 \%$ \\
\hline $\begin{array}{l}\text { Busca de tranquilidade/para se acalmar/ } \\
\text { uso medicinal }\end{array}$ & $5 \%$ & $3 \%$ & $3 \%$ \\
\hline Busca de autoconhecimento/rituais espirituais & $3 \%$ & $2 \%$ & $2 \%$ \\
\hline Não sabe & $5 \%$ & $45 \%$ & $5 \%$ \\
\hline N. A. & $(319)$ & $(2081)$ & $(2400)$ \\
\hline
\end{tabular}

(*) “Experimentaram ao menos uma vez" uma ou mais substâncias das seguintes categorias: (1) estimulantes do sistema nervoso central (SNC) - cocaína ou crack; (2) depressoras do SNC - lança-perfume, loló, cola ou outro solvente, heroína, morfina ou ópio; (3) perturbadoras do SNC: maconha, haxixe, LSD, êxtase, cogumelo (psilocibina), peiote ou san pedro (mescalina), lírio branco ou zabumba.

Fonte: Pesquisa Drogas no Brasil - FPA/RLs (Bokani, 2015). Elaboração própria, com base em banco de dados da pesquisa, disponível no Consórcio de Informações Sociais (CIS) (www.cis.org.br).

de drogas como "curiosidade/vontade de experimentar" (20\%, $5^{\circ}$ lugar) e "prazer/ diversão" (19\%, $6^{\circ}$ lugar), seguidas por "busca de estímulo/energia" (5\%), "busca de tranquilidade" (3\%) e "busca de autoconhecimento" (2\%) - estas últimas mais explicitamente referidas às propriedades das drogas, conforme os três grupos em que as substâncias psicoativas têm sido classificadas, segundo seus efeitos sobre as atividades do sistema nervoso central (Cebrid, 2010).

Como se pode observar (Tabela 3), usuários de drogas confessos explicam as motivações para seu comportamento desviante de modo parcialmente diferente de 
como os não usuários percebem tal prática: embora ainda majoritária, a taxa de "vitimização" social entre os que já experimentaram drogas ilícitas é menor entre usuários (63\%) que entre não usuários (71\%), assim como a de "culpabilização" individual (45\% e 49\%, respectivamente); enquanto a taxa dos que remetem o indivíduo que usa droga a alguma noção de sujeito ativo, embora não chegue a majoritária, é maior entre usuários (46\%) que entre não usuários (37\%).

Sem sobreposição de respostas - ou seja, combinando-se as diferentes percepções sobre as motivações para o consumo de drogas -, consideram o usuário de droga "só vítima e/ou culpado" $57 \%$ da opinião pública (58\% dos não usuários e 50\% dos usuários); consideram o usuário "vítima e/ou culpado e sujeito" $31 \%$ (respectivamente $31 \%$ e 34\%); e "só sujeito" 7\% (respectivamente 6,5\% e 11,5\%).

Política de drogas: opiniões e atitudes

Vejamos agora as atitudes prevalentes na população brasileira em relação a políticas de drogas, de modo a que se possa, na sequência, avaliar como se associam aos comportamentos e às motivações observados ${ }^{15}$.

Cinco perguntas aplicadas no survey em foco trazem opiniões direta ou indiretamente relacionadas com a discussão da política proibicionista vigente. Indagados sobre o que seria melhor para lidar com os usuários de "drogas proibidas", diante de quatro alternativas sugeridas - prisão, tratamento médico, ambas ou nenhuma delas -, quase dois terços manifestaram-se favoráveis a que usuários recebam tratamento médico (64\%) e ainda $4 \%$ a "que possam consumir drogas sem ser presos e sem ser obrigados a fazer tratamento"; menos de um terço manifestou-se favorável à prisão (30\%), seja combinada com tratamento médico (22\%) ou como medida isolada (8\%). Tal resultado indica por si quão defasada está, se não a lei - já que, como comentado, a lei n. 11343/06 não prescreve pena de prisão para usuários mas o efeito prático da lei vigente, dado o encarceramento em massa que há uma década sua aplicação vem provocando.

Diante da questão sobre se está correto que o Estado decida, como ocorre hoje, sobre "quais drogas podem ser consumidas legalmente e quais são proibidas", ou se a

15. Kohlberg recorre à noção durkheimiana da coerção social sob a forma de normas prescritivas que emergem de expectativas socialmente partilhadas, ressaltando o papel do que denomina atmosfera moral na conformação de atitudes diante de dilemas morais (Kohlberg, 1984). As atitudes, por sua vez, como expressão de valores partilhados, informariam o julgamento moral dos indivíduos, exercendo assim influência sobre suas ações e comportamentos, de tal modo que haveria uma tendência para a convergência entre julgamento e ação morais, na medida em que a progressão do indivíduo na trajetória ontogenética da heteronomia para a autonomia implica maior consciência (internalização) da responsabilidade pelos próprios atos (Reed, 1997). 
decisão deveria ser de cada pessoa, a opinião pública mostrou-se mais dividida: $47 \%$ a favor da decisão pelo Estado, 39\% favoráveis à decisão individual. Indagados sobre "que grupos deveriam ter mais peso" na definição das leis e das políticas sobre drogas, entre quatro sugestões - profissionais da saúde, da área jurídica, líderes religiosos e usuários - na soma de duas respostas, "médicos e psicólogos" foram apontados por $81 \%$, “juízes e policiais" por $56 \%$, os próprios usuários por $24 \%$ e religiosos por $18 \%$.

Diante da hipótese de que o governo autorize o consumo da maconha "seja para fins medicinais ou recreativos", entre três possibilidades de gestão sugeridas - fornecimento estatal, com proibição de venda; fiscalização estatal, com controle da venda; ou cada usuário fazendo cultivo para uso próprio -, a fiscalização estatal saiu à frente (36\%), seguida de perto por alternativa não estimulada: "o consumo não deve ser autorizado", reagiram $31 \%$ em resposta espontânea. Apenas 10\% optaram pelo fornecimento estatal, sem venda, e $12 \%$ pela possibilidade de o usuário plantar a própria maconha.

Por fim, a imensa maioria manifestou-se favorável à manutenção da proibição da venda e do consumo de crack (94\%), cocaína (94\%) e maconha (80\%). A alternativa de permitir só o consumo, mantendo a venda proibida, foi indicada por $1 \%$, nos casos do crack e da cocaína, e por $5 \%$ no caso da maconha; e permitir consumo e venda teve o apoio de 3\% (crack), 4\% (cocaína) e 12\% (maconha).

Essas cinco perguntas (oito variáveis) foram trabalhadas de modo a constituírem um índice atitudinal, atribuindo-se pontuações negativas (-1,0 e - 0,5$)$ para as respostas de caráter proibicionista, neutra (zero) para as intermediárias ou indefinidas, e positivas $(0,5$ e 1,0$)$ para as antiproibicionistas, conforme relação a seguir.

Pontuação das respostas para composição do índice atitudinal:

- P11. Melhor política para usuários de drogas ilegais: só prisão -1,0, prisão com tratamento médico $-0,5$, não sabe ou sem resposta 0,0 , só tratamento médico 0,5 , nem prisão nem tratamento 1,0 .

- P12. Quem deve decidir sobre (i)legalidade das drogas: o Estado -1,0, depende, não sabe ou sem resposta 0,0 , o indivíduo 1,0 .

- P13. Grupos que devem ter mais peso na definição da política de drogas: religiosos $-1,0$, juízes e policiais $-0,5$, nenhum desses (resposta espontânea) ou outras respostas - 0,5 ; todos, a sociedade (respostas espontâneas), não sabe ou sem resposta 0,0; médicos e psicólogos 0,5, usuários $1,0^{16}$.

- P23. Gestão da maconha em caso de liberação para uso medicinal ou recreativo: consumo não deve ser autorizado (resposta espontânea) -1,0, não sabe, sem ou

16. Como a pergunta admitia até duas respostas, a pontuação final atribuída a cada indivíduo foi a resultante da soma dos valores atribuídos a cada resposta, guardados os limites de -1,0 e 1,0. 
outra resposta 0,0, Estado deve fiscalizar fornecedores ou deve fornecer 0,5, usuário deve poder plantar a própria maconha 1,0 .

- P17b, e, f. Política para maconha, crack e cocaína: manter proibido o consumo e a venda $-1,0$, não sabe ou sem resposta 0,0 , permitir só o consumo 0,5 , liberar consumo e venda $1,0^{17}$.

A análise da frequência das pontuações obtidas sugeriu a escala de classificação abaixo, obtendo-se a seguinte distribuição dos indivíduos da amostra:

\begin{tabular}{|c|c|c|}
\hline \\
\hline $\begin{array}{l}\text { Muito provicionistas } \\
\text { (de }-5,0 \text { a -2,82) }\end{array}$ & $10 \%$ & \\
\hline $\begin{array}{l}\text { Medianamente proibic } \\
\quad(\mathrm{de}-2,5 \mathrm{a}-1,15)\end{array}$ & $27 \%$ & Proibicionistas: $58 \%$ \\
\hline $\begin{array}{l}\text { Um pouco proibicionist } \\
\text { (de }-1,0 \text { a }-0,35)\end{array}$ & $21 \%$ & \\
\hline $\begin{array}{l}\text { Nem proibicionistas, } \\
\quad(\mathrm{de}-0,34 \text { a } 0,34)\end{array}$ & $\begin{array}{l}\text { cionisto } \\
10 \%\end{array}$ & Intermediários: $10 \%$ \\
\hline $\begin{array}{l}\text { Um pouco antiproibici } \\
(\text { de } 0,35 \text { a } 1,0)\end{array}$ & $15 \%$ & \\
\hline $\begin{array}{l}\text { Medianamente antipro } \\
\quad(\text { de } 1,15 \text { a } 2,5)\end{array}$ & $13 \%$ & Antiproibicionistas: $32 \%$ \\
\hline $\begin{array}{l}\text { Muito antiproibicionist } \\
\text { (de } 2,65 \text { a } 5,0 \text { ) }\end{array}$ & $4 \%$ & \\
\hline
\end{tabular}

Diante do tamanho reduzido da amostra e por parcimônia do modelo, os indivíduos que somaram entre -5,0 e -0,35 foram agrupados em proibicionistas (correspondendo a $58 \%$ dos entrevistados); os que somaram entre 0,35 e 5,0 formaram o grupo dos antiproibicionistas ( $32 \%$ da amostra); aqueles cuja pontuação somou zero $(7,3 \%)$ ou diferente de zero mas entre -0,34 e 0,34 (a título de margem de segurança) foram classificados de intermediários (10\% da amostra).

Isso feito, cruzou-se a síntese do índice atitudinal com o resultado de usuários/ nunca usuários de drogas ilícitas, obtendo-se a distribuição que consta na Tabela 4.1.

Como era esperado, a presença de antiproibicionistas é maior entre usuários de drogas (46\%) que entre não usuários (30\%) e, inversamente, a taxa de proibicionistas é claramente majoritária (61\%) entre os não usuários (Tabela 4.1). Sobre o total da amostra, essa mesma distribuição apresenta-se na Tabela 4.2. Assim, da relação entre o comportamento declarado quanto ao consumo de drogas ilícitas e o índice atitu-

17. Para cada indivíduo, a soma da pontuação das três variáveis dessa pergunta foi dividida por 3 para que ao final pudesse equivaler ao mesmo peso dado às demais perguntas do índice. 
TABELA 4.1

\begin{tabular}{l|cc|c}
\hline & \multicolumn{3}{|c}{ Consumo DE ILÍCITA } \\
\hline ÍNDice ATItUdinal & Qualquer $^{(*)}$ & Nenhuma & TotAL \\
\hline Proibicionista & $40 \%$ & $61 \%$ & $58 \%$ \\
Intermediário & $14 \%$ & $9 \%$ & $10 \%$ \\
Antiproibicionista & $46 \%$ & $30 \%$ & $32 \%$ \\
\hline N. A. & $(319)$ & $(2081)$ & - \\
\hline
\end{tabular}

(*) “Experimentaram ao menos uma vez” uma ou mais substâncias das seguintes categorias: (1) estimulantes do sistema nervoso central (SNC) - cocaína ou crack; (2) depressoras do SNC - lança-perfume, loló, cola ou outro solvente, heroína, morfina ou ópio; (3) perturbadoras do SNC: maconha, haxixe, LSD, êxtase, cogumelo (psilocibina), peiote ou san pedro (mescalina), lírio branco ou zabumba.

Fonte: Pesquisa Drogas no Brasil - FPA/RLS (Bokani, 2015). Elaboração própria, com base em banco de dados da pesquisa, disponível no Consórcio de Informações Sociais (CIS) (www.cis.org.br).

TABELA 4.2

\begin{tabular}{l|cc|c}
\hline & \multicolumn{3}{|c}{ Consumo DE ILÍ́cita } \\
\hline Índice Atitudinal & Qualquer & Nenhuma & Total \\
\hline Proibicionista & $5 \%$ & $53 \%$ & $58 \%$ \\
Intermediário & $2 \%$ & $8 \%$ & $10 \%$ \\
Antiproibicionista & $6 \%$ & $26 \%$ & $32 \%$ \\
\hline Sobre total da amostra & $13 \%$ & $87 \%$ & - \\
N. A. & $(319)$ & $(2081)$ & - \\
\hline
\end{tabular}

Fonte: Pesquisa Drogas no Brasil - FPA/RLS (Bokani, 2015). Elaboração própria, com base em banco de dados da pesquisa, disponível no Consórcio de Informações Sociais (CIs) (www.cis.org.br).

dinal, relativo às percepções e opiniões sobre a questão das drogas, temos a seguinte síntese (Tabela 4.2): em uma diagonal, dois grupos que podem ser designados como coerentes - os não usuários proibicionistas, que constituem maioria absoluta (53\%), e os usuários de ilícitas antiproibicionistas, que somam 6\%; na outra diagonal, dois grupos aparentemente contraditórios, nos quais comportamento e atitude seguem em sentidos opostos - os não usuários antiproibicionistas, que constituem um quarto da amostra (26\%), e os usuários proibicionistas (5\%). Como apontado na introdução, o enigma sobre o qual se busca compreensão concentra-se nesses dois últimos grupos, na medida em que não permitem uma resposta imediata, prévia ou evidente que explique ou justifique a incoerência entre seu comportamento declarado e a atitude manifesta. 
Para concluir o tratamento dos dados, tomemos a classificação dos grupos coerentes e contraditórios como variável-resposta (dependente) de uma análise de regressão logística multinomial, com vistas a identificar as variáveis independentes preditoras de tais posicionamentos - ou seja, mais fortemente a ela associadas ${ }^{18}$. Trata-se de buscar evidências para a verificação de duas hipóteses complementares: os grupos com posicionamento à primeira vista contraditório (1) diferem entre si porquanto refletem indivíduos situados em níveis de moralidade ou perspectivas sociomorais distintas - pós-convencional, de um lado, convencional ou pré-convencional, de outro; (2) aparência contraditória à parte, a seu modo cada um desses posicionamentos é internamente coerente e pode ser compreendido à luz da teoria psicossocial construtivista (kohlberguiana) do desenvolvimento moral.

Com o uso do pacote estatístico spss, fixado o grupo majoritário dos não usuários proibicionistas como categoria de referência, construiu-se uma regressão em três etapas (utilizando-se o modelo de efeitosprincipais): a primeira etapa com onze variáveis independentes, sendo sete sociodemográficas (sexo, raça/cor, religião, idade, escolaridade, renda per capita e posição na - ou atividade fora da - força de trabalho), três variáveis de contexto (residência em região metropolitana ou no interior, em zona urbana ou rural e presença de familiar usuário de ilícita ou com dependência alcoólica no domicílio) e uma comportamental (uso de álcool e tabaco). Nas etapas seguintes foram sucessivamente removidas as variáveis cujos efeitos não se mostraram significativos para explicar a variabilidade da variável resposta, de modo que ao fim apenas seis variáveis se consolidaram como relevantes para o modelo ${ }^{19}$. Considerando-se os dois grupos contraditórios, obteve-se o seguinte resultado:

- Para o caso dos não usuários antiproibicionistas, identificaram-se quatro variáveis

18. Agradeço ao estatístico José Reinaldo Riscal pela orientação para o desenvolvimento do modelo de regressão e para a descrição dos resultados obtidos.

19. A variável raça/cor, com as categorias do IBGE agrupadas em branca, negra (parda e preta) e outras (amarela, indígena e outras) mostrou-se irrelevante para o modelo já na $1^{\text {a }}$ etapa; residir em RM versus interior e em área urbana versus rural mostraram-se não significantes na $2^{\text {a }}$ etapa; renda mensal per capita e pertença ou não à força de trabalho perderam relevância na $3^{a}$ etapa. O critério para a definição da categoria de controle de cada variável independente foi privilegiar aquelas que apresentavam a maior taxa de não usuários proibicionistas - ou seja, que tendiam para a categoria de referência da variável dependente. Nas variáveis de natureza escalar, como faixa etária, grau de escolaridade e faixa de renda per capita, foram fixadas como categorias de controle aquelas do extremo, em que essa taxa era mais alta (respectivamente, idosos, com menor escolaridade e menor renda). Na variável raça/cor optou-se pela "neutra" outras e na variável religião, pela "intermediária” católico não praticante como categorias de controle. 
importantes: idade, escolaridade, religião e ter familiar no domicílio usuário regular de ilícita(s) ou dependente químico de álcool, sendo que religião e idade com uma importância relativa um pouco maior no modelo ( $31 \%$ e $28 \%$, respectivamente) que escolaridade e perfil de composição familiar (20,5\% cada).

A chance de ser não usuário antiproibicionista mostrou-se (Tabela 5.1):

- Segundo a idade, $82 \%$ maior para os jovens de 16 a 24 anos, $81 \%$ maior para adultos de 25 a 39 anos e 66\% maior para adultos de 40 a 59 anos, comparativamente nos três casos - à categoria-controle idosos (60 anos e mais).

- Segundo a escolaridade, 54\% maior para os que chegaram ao Ensino Superior (ES), 38\% maior para os que foram até o Ensino Médio (EM) e 45\% maior para os que pararam no Ensino Fundamental II (EF II), comparativamente - nos três casos - à categoria dos que não ultrapassaram o EF I.

- Segundo a convivência com familiares, 55\% maior entre os que têm no domicílio usuário de droga ilícita, comparativamente aos que não têm essa convivência, nem com familiar com uso abusivo de álcool.

- Segundo a religião, 25\% menor para evangélicos, comparativamente à categoria-controle dos católicos não praticantes ${ }^{20}$.

Para o caso dos usuários proibicionistas, além de idade, escolaridade e ter familiar no domicílio usuário regular de ilícita(s) ou dependente químico de álcool, outras duas variáveis - sexo e uso de álcool e tabaco - mostraram-se importantes, enquanto religião perdeu relevância ${ }^{21}$ (Tabela 5.2).

Com destaque para idade e uso de álcool e tabaco (32,5\% e 32\% de importância relativa na composição do modelo), seguidas por escolaridade (13,5\%), sexo (10,5\%) e práticas com drogas na família (10\%), a chance de ser usuário proibicionista mostrou-se:

- Segundo a idade, cerca de treze vezes maior para os jovens de 16 a 24 anos e para

20. E $18 \%$ menor também para católicos praticantes, se admitíssemos um nível de significância da ordem de $10 \%(p=0,11)$, em vez de $5 \%$.

21. Com nível de significância da ordem de $10 \%$ religião mantém relevância em relação à chance de ser usuário proibicionista - 70\% maior para os sem religião e ateus, comparados aos católicos não praticantes $(p=0,08)$ - assim como a inserção na força de trabalho mostrara-se relevante na $2^{\text {a }}$ etapa: seria duas vezes maior $(200 \%)$ para os que estão no mercado informal $(p=0,93)$ e cerca de 2,5 vezes maior (261\%) para os desempregados $(\mathrm{p}=0,89)$, comparativamente aos aposentados. 
TABELA 5.1

\begin{tabular}{|c|c|c|c|c|c|c|}
\hline \multirow[b]{2}{*}{ Parameter Estimates } & \multicolumn{6}{|c|}{ REGRESSÃO LOGÍSTICA MULTINOMIAL } \\
\hline & в & Std. Error & Wald & df & Sig. & $\operatorname{Exp}(B)$ \\
\hline \multicolumn{7}{|l|}{ Não usuário antiproibicionista } \\
\hline Intercept & $-1,515$ & 0,192 & 62,01 & 1 & 0 & - \\
\hline [Relig=1] Espírita & 0,361 & 0,271 & 1,768 & 1 & 0,184 & 1,434 \\
\hline [Relig=2] Sem religião/ ateu & 0,213 & 0,178 & 1,426 & 1 & 0,232 & 1,237 \\
\hline [Relig=3] Evangélico/a & $-0,293$ & 0,144 & 4,116 & 1 & $0,042^{(* *)}$ & 0,746 \\
\hline [Relig=4] Católico/a praticante & $-0,206$ & 0,13 & 2,513 & 1 & $0,113^{(*)}$ & 0,814 \\
\hline [Relig=5] Católico/a não pratic. & - & - & - & 0 & - & - \\
\hline$[\mathrm{Alc} \& \mathrm{Tab}=1]$ Usa ambos & 0,238 & 0,184 & 1,677 & 1 & 0,195 & 1,269 \\
\hline$[$ Alc $\& T a b=2]$ Usa um ou outro & 0,167 & 0,125 & 1,794 & 1 & 0,18 & 1,182 \\
\hline$[\mathrm{Alc} \& \mathrm{Tab}=3]$ Ex usuário & 0,184 & 0,144 & 1,627 & 1 & 0,202 & 1,202 \\
\hline$[$ Alc\&Tab=1] Nunca usou & - & - & - & 0 & - & - \\
\hline [Idade $=1] 16$ a 24 anos & 0,598 & 0,188 & 10,083 & 1 & $0,001^{(* * *)}$ & 1,819 \\
\hline [Idade $=2] 25$ a 39 anos & 0,591 & 0,174 & 11,514 & 1 & $0,001^{(* * *)}$ & 1,805 \\
\hline [Idade $=3$ ] 40 a 59 anos & 0,509 & 0,167 & 9,305 & 1 & $0,002^{(* * *)}$ & 1,664 \\
\hline$[$ Idade $=4] 60$ anos e + & - & - & - & 0 & - & - \\
\hline$[$ Sexo $=1]$ Masculino & $-0,04$ & 0,103 & 0,149 & 1 & 0,7 & 0,961 \\
\hline$[$ Sexo=2] Feminino & - & . & . & 0 & . & . \\
\hline$[$ Escola=1] Ensino Superior & 0,433 & 0,197 & 4,864 & 1 & $0,027^{(* *)}$ & 1,543 \\
\hline [Escola=2] Ensino Médio & 0,325 & 0,154 & 4,467 & 1 & $0,035^{(* *)}$ & 1,384 \\
\hline$[$ Escola=3] E. Fundamental II & 0,371 & 0,159 & 5,432 & 1 & $0,02^{(* *)}$ & 1,45 \\
\hline$[$ Escola=4] E. Fundamental I & - & - & - & 0 & - & - \\
\hline [Alc\&ilic_fam=1] Tem ambos & 0,225 & 0,19 & 1,411 & 1 & 0,235 & 1,252 \\
\hline [Alc\&ilic_fam=2] Só de ilícita & 0,437 & 0,184 & 5,663 & 1 & $0,017^{(* *)}$ & 1,549 \\
\hline [Alc\&ilic_fam=3] Só de álcool & 0,054 & 0,14 & 0,149 & 1 & 0,699 & 1,056 \\
\hline [Alc\&ilic_fam=4] Não tem & - & - & - & 0 & - & - \\
\hline
\end{tabular}

${ }^{(*)}$ Significante a $10 \% ;{ }^{(* *)}$ Significante a $5 \% ;{ }^{(* *)}$ Significante a menos de $1 \%$.

Fonte: Pesquisa Drogas no Brasil - FPA/RLs (Bokani, 2015). Elaboração própria, com base em banco de dados da pesquisa, disponível no Consórcio de Informações Sociais (CIs) (www.cis.org.br). 
TABELA 5.2

\begin{tabular}{|c|c|c|c|c|c|c|}
\hline \multirow[b]{2}{*}{ Parameter Estimates } & \multicolumn{6}{|c|}{ REGRESSÃO LOGÍSTICA MULTINOMIAL } \\
\hline & в & Std. Error & Wald & $\mathrm{df}$ & Sig. & $\operatorname{Exp}(B)$ \\
\hline \multicolumn{7}{|l|}{ Usuário proibicionista } \\
\hline Intercept & $-7,734$ & 0,853 & 82,254 & 1 & 0 & - \\
\hline [Relig=1] Espírita & $-0,835$ & 0,768 & 1,183 & 1 & 0,277 & 0,434 \\
\hline$[$ Relig=2] Sem religião/ateu & 0,528 & 0,3 & 3,099 & 1 & $0,078^{(*)}$ & 1,696 \\
\hline [Relig=3] Evangélico/a & 0,356 & 0,276 & 1,664 & 1 & 0,197 & 1,428 \\
\hline [Relig=4] Católico/a praticante & $-0,45$ & 0,289 & 2,433 & 1 & $0,119^{(*)}$ & 0,638 \\
\hline [Relig=5] Católico/a não praticante & - & - & - & 0 & - & - \\
\hline$[$ Alc\&Tab $=1]$ Usa ambos & 2,597 & 0,401 & 41,989 & 1 & $0^{(* * *)}$ & 13,421 \\
\hline$[\mathrm{Alc} \& \mathrm{Tab}=2]$ Usa um ou outro & 1,73 & 0,365 & 22,515 & 1 & $0^{(* * *)}$ & 5,643 \\
\hline$[\mathrm{Alc} \& \mathrm{Tab}=3]$ Ex usuário & 1,827 & 0,382 & 22,935 & 1 & $0^{(* * *)}$ & 6,218 \\
\hline$[$ Alc $\& T a b=1]$ Nunca usou & - & - & - & 0 & - & - \\
\hline$[$ Idade $=1] 16$ a 24 anos & 2,641 & 0,751 & 12,365 & 1 & $0^{(* * *)}$ & 14,03 \\
\hline$[$ Idade $=2] 25$ a 39 anos & 2,649 & 0,738 & 12,878 & 1 & $0^{(* * *)}$ & 14,139 \\
\hline [Idade $=3] 40$ a 59 anos & 1,959 & 0,744 & 6,935 & 1 & $0,008^{(* * *)}$ & 7,094 \\
\hline$[$ Idade $=4] 60$ anos e + & - & - & - & 0 & - & - \\
\hline$[$ Sexo $=1]$ Masculino & 0,951 & 0,212 & 20,118 & 1 & $0^{(* * *)}$ & 2,589 \\
\hline$[\mathrm{Sexo}=2]$ Feminino & - & - & - & 0 & - & - \\
\hline [Escola=1] Ensino Superior & 1,093 & 0,444 & 6,046 & 1 & $0,014^{(* *)}$ & 2,983 \\
\hline$[$ Escola=2] Ensino Médio & 0,94 & 0,383 & 6,016 & 1 & $0,014^{* *)}$ & 2,56 \\
\hline [Escola=3] Ensino Fundamental II & 0,827 & 0,401 & 4,256 & 1 & $0,039^{(* *)}$ & 2,286 \\
\hline$[$ Escola $=4]$ Ensino Fundamental I & - & - & - & 0 & - & - \\
\hline [Alc\&ilic_fam=1] Tem ambos & 0,821 & 0,308 & 7,098 & 1 & $0,008^{(* * *)}$ & 2,272 \\
\hline [Alc\&ilic_fam=2] Só de ilícita & 0,591 & 0,317 & 3,48 & 1 & $0,062^{(*)}$ & 1,805 \\
\hline [Alc\&ilic_fam=3] Só de álcool & 0,576 & 0,258 & 4,961 & 1 & $0,026^{(* *)}$ & 1,778 \\
\hline$[$ Alc\&ilic_fam=4] Não tem & - & - & - & 0 & - & - \\
\hline
\end{tabular}

${ }^{(*)}$ Significante a $10 \% ;{ }^{(*)}$ Significante a $5 \% ;{ }^{(* *)}$ Significante a menos de $1 \%$.

Fonte: Pesquisa Drogas no Brasil - FPA/RLS (Bokani, 2015). Elaboração própria, com base em banco de dados da pesquisa, disponível no Consórcio de Informações Sociais (CIs) (www.cis.org.br). 
adultos de 25 a 39 anos (1303\% e $1314 \%$, respectivamente) e seis vezes maior (609\%) para adultos de 40 a 59 anos, comparativamente aos idosos (60 e mais).

- Segundo o sexo, 159\% maior para os homens, em comparação à categoria-controle mulheres;

- Segundo a escolaridade, duas vezes maior (198\%) para os que chegaram ao ES, $156 \%$ maior para os que foram até o EM e $129 \%$ maior para os que pararam no EF II, comparativamente aos que não ultrapassaram o EF I.

- Segundo a convivência com familiares, $127 \%$ maior entre os que têm no domicílio usuário de droga ilícita e com uso abusivo de álcool, 81\% e 78\% maior entre os que convivem com um ou com outro, respectivamente, em comparação aos que não têm tais convivências;

- Segundo o uso de tabaco e álcool, cerca de 12,5 vezes maior (1242\%) para usuários de ambos, 4,5 vezes maior (462\%) para usuários de um ou de outro e cerca de cinco vezes maior para ex-usuários de um e/ou de outro (522\%), comparativamente à categoria-controle dos que nunca usaram tabaco nem álcool.

Os achados sobre as variáveis observadas como preditores relevantes, seja para a posição de não usuário antiproibicionista, seja para a posição de usuário proibicionista, oferecem indícios empíricos que apontam para a confirmação da hipótese de que nesses grupos concentram-se indivíduos que veem a questão das drogas a partir de perspectivas sociomorais distintas.

Para a teoria kohlberguiana do desenvolvimento moral, opor-se às normas e às regras, por si só, não expressa necessariamente uma postura pós-convencional, na medida em que um argumento em apoio a um comportamento desviante ou transgressor também pode ser expressão de uma perspectiva pré-convencional, de quem raciocina moralmente de um ponto de vista egocêntrico ${ }^{22}$. A postura de não usuário antiproibicionista, no entanto, sugere a presença de elementos de moralidade autônoma ao atender, à primeira vista, alguns critérios formais que a caracterizam - a saber, o da reversibilidade, que implica o exercício de assunção de papéis (a capacidade de se colocar no lugar dos diferentes atores envolvidos em um conflito), já que quem se opõe ao proibicionismo sem usar droga não está, ao menos de forma direta, advogando em causa própria; o construtivismo, que implica a consciência de que regras e leis são construções histórico-culturais: mesmo quando em sua origem expressam consensos, são passíveis de se tornarem inadequadas, podendo/devendo ser altera-

22. O que nos impede de considerar os usuários antiproibicionistas como portadores de uma moralidade autônoma é não podermos avaliar a fundo as razões morais dos respondentes do survey, visto que sua "coerência" também pode ser expressão de interesses particulares, com baixo ou nenhum potencial de universalização. 
das (consciência ao menos latente em quem as questiona); e o critério da liberdade, que implica julgamentos morais livres de constrangimentos externos, advindos de autoridade legal, religiosa ou da tradição ${ }^{23}$.

Como a aquisição de tais critérios de julgamento autônomo tende a estar mais presente quanto maior o acesso à escolaridade e com a diminuição da submissão a autoridades religiosas, os achados que associam maior chance de indivíduos não usuários antiproibicionistas ao aumento da escolaridade e menor chance entre evangélicos e católicos praticantes constituem indícios empíricos que convergem para confirmar a hipótese de que nesse grupo se concentram indivíduos que veem a questão das drogas a partir de uma perspectiva autônoma.

Já em relação à postura de usuário proibicionista, a teoria kohlberguiana sugere a presença de critérios de julgamento moral semiautônomos (convencionais) e tipicamente heterônomos (pré-convencionais), seja como assunção do que está na lei como necessariamente correto, seja tendo a lei como regra que não precisa ser seguida, desde que se possa escapar da punição ao transgredi-la. Assim, o achado de que com a diminuição da idade aumente tanto a chance de o indivíduo estar na posição de usuário proibicionista pode ser expressão da dificuldade de se ultrapassar a perspectiva convencional, de se romper argumentativamente com os valores hegemônicos, mesmo quando se age contrariamente a eles. A incapacidade de justificar ou defender um comportamento transgressor, mesmo entre os mais escolarizados deste grupo, pode refletir a força da internalização de tais valores e o apelo à manutenção da ordem, ainda quando admitem ter cometido eventuais desvios. Por fim, o fato de aumentar tanto a chance de ser usuário proibicionista entre usuários e ex-usuários de tabaco e/ou de álcool, sobretudo se atual consumidor de ambos, parece refletir um acúmulo ou a sobreposição de estigmas que decorrem do uso de drogas mesmo legais, dificultando a justificação do comportamento propriamente desviante, relativo ao consumo das ilícitas.

Em suma, se não constituem evidências contundentes ou conclusivas, os achados que emergem da análise de regressão apontam antes para a sustentação que para a negação da hipótese relativa a estarmos diante de diferentes perspectivas sociomorais, sobre as quais se assentam os posicionamentos (espero que já compreensíveis e não contraditórios) de não usuários antiproibicionistas e usuários proibicionistas. Ao mesmo tempo, o fato de que a convivência com familiar usuário de droga ilícita e/ou dependente químico de álcool tenha se mantido como variável de contexto preditora de ambos os posicionamentos - acaso o convívio gera compreensão e

23. Sobre o lugar desses critérios formais na construção do tipo ideal de moralidade autônoma, ver Colby e Kohlberg (1987) e Venturi (2003). 
empatia, ao acelerar ou incrementar as oportunidades de assunção de papéis, ou provoca sofrimentos e frustrações, paralisando fluxos afetivos e gerando rupturas? soma-se a outras questões não respondidas. Isso ressalta as limitações e a insuficiência da abordagem de questões relativas a níveis de moralidade com base tão somente no enfoque quantitativo - típico da técnica do survey -, invocando a necessidade de enfoques de natureza qualitativa.

Tal constatação reforça o potencial da abordagem interacionista e construtivista, aqui utilizada, para abordar de modo profícuo o tema em foco, visto que seus principais formuladores, Piaget e Kohlberg, a desenvolveram com base em pesquisas empíricas assentadas em técnicas qualitativas ${ }^{24}$. Um retorno aos dados de natureza mais qualitativa do próprio survey - aferidos pela pergunta aberta sobre as motivações para as pessoas usarem drogas - também ratifica essa ideia: vimos que $71 \%$ dos não usuários explicam o uso de drogas por fatores de socialização e de contexto social (enfoque vitimizador); entre os usuários proibicionistas essa taxa cai para $64 \%$ e entre os usuários antiproibicionistas, para 60\%; se 49\% dos não usuários mobilizam respostas culpabilizadoras para explicar o uso de drogas (agrupáveis em "debilidades individuais"), essa taxa mantém-se no mesmo patamar entre usuários proibicionistas (51\%), sintoma novamente de sua autoculpabilização de cunho heterônomo, mas cai para $42 \%$ entre os usuários antiproibicionistas; e se $37 \%$ dos não usuários explicam o consumo de drogas reconhecendo alguma dimensão de sujeito nos usuários (apenas 6,5\% como explicação única), essa taxa de novo mantém o patamar (40\%) entre usuários proibicionistas (9,5\% como explicação exclusiva), mas chega à metade (50\%) entre os usuários antiproibicionistas ( $14 \%$ como explicação única), provável expressão de um uso de drogas menos ou não abusivo e mais autônomo nesse grupo.

\section{Considerações finais}

O uso de substâncias psicoativas é um fenômeno social universal, presente em todas as épocas e culturas. Varia apenas o status que as drogas adquirem, ao longo do tempo e em cada sociedade, ora umas, ora outras, ao terem sua produção e distribuição regulamentadas ou, ao contrário, relegadas à informalidade e ilegalidade, na tentativa invariavelmente fracassada de que não sejam consumidas.

No Brasil atual, consideradas as ilícitas e sobretudo as lícitas, lideradas pelo consumo frouxamente fiscalizado das bebidas alcoólicas, o uso de drogas é um

24. Ver Piaget ([1932] 1977) e Colby e Kohlberg (1987). 
fenômeno "democrático": atinge todas as classes sociais, faixas etárias, religiosos de todas as confissões e não religiosos, indistintamente se residentes em regiões metropolitanas ou em municípios do interior, se no meio urbano ou rural, em todas as regiões do país. Varia por segmento ou por tipo de droga - os homens consomem mais que as mulheres, os sem religião e espíritas mais que os evangélicos e católicos praticantes, os que estão na força de trabalho mais que os que estão fora dela; o tabaco é mais consumido em segmentos com baixa escolaridade, no mercado informal ou entre desempregados, o álcool mais nos segmentos com escolaridade superior ou no mercado formal, as drogas ilícitas mais entre os jovens, entre os mais escolarizados ou sem religião - mas legais ou ilegais, as drogas estão presentes em todos os grupos sociais.

A percepção da opinião pública captada pelo survey - majoritariamente favorável a que o consumo de drogas seja enfrentado como uma questão antes de saúde do que de segurança pública - expõe o atraso da política brasileira para substâncias que considera ilícitas (na prática ainda refém da diretriz estadunidense de "guerra às drogas"), indicando a necessidade de se alterar o paradigma proibicionista vigente. Mas se a possibilidade de que se avance em direção à adoção de medidas antiproibicionistas está dada, não são claras a extensão e a velocidade com que essa mudança possa ser feita, caso se tenha como critério legitimador do processo a busca de consenso social, o apoio majoritário da opinião pública. Afinal, a passagem do enfoque do consumo de drogas de "caso de polícia" para "caso médico" reflete antes uma postura em prol da redução de danos; a maioria permanece contrária à liberação do consumo e sobretudo da venda mesmo das drogas ilícitas mais usadas, como a maconha e a cocaína. Como e quanto avançar?

A análise dos comportamentos declarados e das atitudes manifestas apontou grupos da população brasileira cujas práticas de uso e posturas ante a política de consumo de drogas ilícitas se encontram em aparente contradição - os usuários de drogas ilícitas proibicionistas e os não usuários antiproibicionistas. A abordagem dessa questão pela teoria psicossocial kohlberguiana da moralidade permitiu entender tais dissonâncias como expressão de diferentes níveis de desenvolvimento moral e ofereceu pistas para o enfrentamento do impasse: proibicionistas, usuários ou não, constituem a maioria da população, e estariam presos a padrões convencionais (eventualmente até pré-convencionais) de julgamento moral; os antiproibicionistas, sobretudo se não usuários, expressariam postura descentrada e moralmente autônoma, pós-convencional, socialmente minoritária.

Ou seja, pela ótica construtivista do desenvolvimento moral, ainda que se possa esperar que medidas alterando a política de drogas na direção antiproibicionista tendam a ser assimiladas pela maioria convencional se vindas de cima, como deliberações 
do $\mathrm{STF}^{25}$, é provável que mudanças na política de drogas possam avançar mais, com maior consistência e respaldo social, se forem apoiadas por um contingente maior de cidadãos moralmente autônomos. Considerando que o processo de desenvolvimento da heteronomia para a autonomia moral tem como principal propulsor interações sociais horizontais e dialógicas - não autoritárias - de modo a favorecer o exercício da reciprocidade e o respeito à alteridade, uma política de drogas inspirada na aplicação de tais procedimentos depende da promoção de amplo debate público, que leve em conta as vozes dos diferentes atores envolvidos no dilema enfrentado. Nesse sentido, cabe incorporar a perspectiva - até hoje pouco ou nada considerada - dos usuários de drogas ilícitas, parte considerável dos quais, como se viu, explica seu comportamento transgressor pela demanda por um consumo recreativo das drogas, provavelmente sustentada por um enfoque autônomo radical (hipótese a ser investigada), como quem diz "sobre meu corpo, o Estado sou eu".

É fato que uma maior adesão a práticas religiosas conservadoras cristãs mostra alguma eficácia na contenção do uso de drogas, parecendo, assim, um bom caminho para o enfrentamento do problema do consumo abusivo e do envolvimento com a criminalidade - como se viu, estão entre evangélicos e católicos praticantes as menores taxas de uso de álcool, tabaco e de ilícitas, marcando uma distinção comportamental importante para a afirmação dessas identidades religiosas ${ }^{26}$. A pertença a essas confissões constitui-se, no entanto, em um obstáculo ou fator de retardamento para o avanço de uma perspectiva pós-convencional antiproibicionista, dada a tendência à abdicação da reflexão autônoma a que seus membros engajados estão sujeitos por conta da disciplina devida e da maior exposição à influência das autoridades pastorais de suas igrejas. Em outras palavras, um enfrentamento da questão que permita desarmar a dinâmica socialmente perversa que envolve hoje o consumo de drogas, parece ser uma tarefa que exige menos a renovação de atos de fé e mais a construção de espaços de interação social que facilitem o exercício da razão dialógica ${ }^{27}$.

Por fim, de um ponto de vista metodológico, ficaram evidentes a insuficiência e as limitações para uma análise conclusiva sobre os tipos de moralidade e as perspectivas sociomorais que afloram na opinião pública, quando se trata da questão sob a ótica da psicologia social kohlberguiana com base tão somente em dados quantitativos,

25. Do Congresso Nacional, em sua configuração atual e mais parecido que é com a cara conservadora do povo brasileiro, não é razoável esperar que venham.

26. Agradeço ao sociólogo Ricardo Mariano pelas considerações que me permitiram tal observação.

27. A ocorrência em escala global de desfechos políticos que denotam (e renovam) irracionalidades, como a eleição de Donald Trump nos Estados Unidos, antes reforça a relevância da escolha moral por esse caminho do que atesta sua inviabilidade. 
gerados por um survey. A impossibilidade de avaliar quais usuários antiproibicionistas seriam pós-convencionais, quais seriam apenas pré-convencionais advogando em causa própria, entre outras questões não respondidas, ressalta a necessidade do desenvolvimento de pesquisas qualitativas - com entrevistas clínicas e aplicação de dilemas morais, a exemplo das técnicas utilizadas pelos elaboradores dessa abordagem construtivista (Piaget, [1932] 1977; Colby e Kohlberg, 1987) - para um enfrentamento teórico e prático mais aprofundado da questão do consumo de drogas e da discussão das políticas públicas a ela dirigidas. Há, portanto, uma dupla agenda de pesquisas, teórica e empírico-metodológica, a ser trabalhada.

\section{Referências Bibliográficas}

Becker, Howard Saul. ([1963] 2008), Outsiders: estudos de sociologia dos desvios. Rio de Janeiro, Zahar.

BoKany, Vilma (org.). (2015), Drogas no Brasil: entre a saúde e a justiça: proximidades e opiniões. São Paulo, Fundação Perseu Abramo.

Campos, Marcelo da Silveira. (2015a), "As percepções dos brasileiros sobre drogas, justiça e saúde”. In: BoKAnY, Vilma (org.). (2015), Drogas no Brasil: entre a saúde e a justiça: proximidades e opiniões. São Paulo, Fundação Perseu Abramo.

(2015b), "Drogas e justiça criminal em São Paulo: uma análise da origem social dos criminalizados por drogas desde 2004 a 2009”. Revista de Sociologia da UFSCar, 1 (5): 167-189.

CEBRID - Centro Brasileiro de Informações sobre Drogas Psicotrópicas. (2010), Drogas psicotrópicas: livreto informativo. 6. ed. São Paulo, Secretaria Nacional de Políticas sobre Drogas.

Colby, Anne \& Kohlberg, Lawrence. (1987), The measurement of moral judgment. Cambridge, Cambridge University Press, vol. 1.

Daniel, Herbert. (1991), “A Aids é um tigre de papel... higiênico”. In: Daniel, H. \& PARKer, R. Aids, a terceira epidemia: ensaios e tentativas. São Paulo, Iglu.

Escohotado, Antonio. (1997), O livro das drogas. São Paulo, Dynamis.

Jesus, Maria Gorete M. et al. (2011), Prisão provisória e lei de drogas: um estudo sobre os flagrantes de tráfico de drogas na cidade de São Paulo. São Paulo, Núcleo de Estudos da Violência - USP.

Kohlberg, Lawrence. (1981), Essays on moral development. Vol. 1: The philosophy of moral development. São Francisco, Harper \& Row.

. (1984), Essays on moral development. Vol. 2: The psychology of moral development. São Francisco, Harper \& Row.

Lemieux, Cyril. (2015), “Problematizar”. In: Paugam, Serge. (2015), A pesquisa sociológica. Petrópolis, Vozes.

Macrae, Edward \& Simões, Julio Assis. (2003), “A subcultura da maconha, seus valores e 
rituais entre setores socialmente integrados". In: BAptista, M. et al. (orgs.). Drogas e pós-modernidade. Vol. 2: Faces de um tema proscrito. Rio de Janeiro, UERJ.

"Ministro da Justiça quer erradicar comércio e uso de maconha no Brasil”. (2016), uOL Notícias.

Disponível em http://noticias.uol.com.br/ultimas-noticias/agencia-estado/2016/12/17/ ministro-da-justica-quer-erradicar-comercio-e-uso-de-maconha-no-brasil.htm, consultado em 4/1/2017.

PiAget, Jean. ([1932] 1977), O julgamento moral na criança. São Paulo, Mestre Jou.

Pizano, Ernesto Samper. (2013), Drogas: prohibición o legalización. Bogotá, Mondadori.

REED, Donald R. C. (1997), Following Koblberg: liberalism and the practice of democratic community. Notre Dame, University of Notre Dame Press.

SAntos, Gevanilda \& Silva, Maria Palmira da (orgs.). (2005), Racismo no Brasil: percep̧ões da disciminação e do preconceito racial no século XXI. São Paulo, Fundação Perseu Abramo/ Fundação Rosa Luxemburg.

Sousa Pinto, Ana Estela de. (2016), "Duterte acusa 6 mil políticos de narcotráfico e promete punição”. Folha On-Line. 29/12. Disponível em http://www1.folha.uol.com.br/ mundo/2016/12/1845487-duterte-acusa-6000-politicos-de-narcotrafico-e-promete-punicao.shtml, consultado em 10/1/2017.

Velho, Gilberto. (1994), Projeto e metamorfose: antropologia das sociedades complexas. Rio de Janeiro, Jorge Zahar.

Venturi, Gustavo. (2003), Democracia e autonomia moral: universalismo moral e relativismo ético em teorias normativas da democracia. São Paulo, tese de doutorado, Departamento de Ciência Política, Faculdade de Filosofia, Letras e Ciências Humanas da Universidade de São Paulo.

. (2016), "Cultura de violência e drogas ilícitas no cotidiano juvenil". In: NovaEs,

R. et al. (orgs.). Agenda Juventude Brasil: leituras sobre uma década de mudanças. Rio de Janeiro, Unirio.

\& Bokany, Vilma (orgs.). (2011), Diversidade sexual e homofobia no Brasil. São Paulo, Fundação Perseu Abramo.

\section{Resumo}

Consumo de drogas, opinião pública e moralidade: motivações e argumentos baseados em uso Este artigo analisa dados de um survey nacional de 2013, representativo da população brasileira com 16 anos e mais, que abordou percepções, práticas e opiniôes sobre o uso de drogas psicoativas no Brasil. Descreve o comportamento de diferentes segmentos sociodemográficos quanto ao consumo de álcool, tabaco e drogas ilícitas, relacionando-o a uma escala atitudinal, construída como síntese de oito variáveis com opinióes sobre consumo e política para drogas hoje ilegais. Recorre à técnica de regressão logística multinomial para identificar as variáveis preditoras de dois posicionamentos à primeira vista contraditórios, em termos de dissonância entre compor- 
tamento declarado e atitude manifesta: os usuários de drogas ilícitas proibicionistas - favoráveis à manutenção da política de drogas vigente, que criminaliza o consumo e prioriza o enfoque do problema como questão de segurança pública - e os não usuários antiproibicionistas. Analisa tais posicionamentos à luz da teoria psicossocial construtivista da moralidade, desenvolvida por Jean Piaget e Lawrence Kohlberg, expondo seu potencial para compreendê-los e para abordar a discussão das políticas públicas voltadas para lidar com o fenômeno universal do consumo de substâncias psicoativas.

Palavras-chave: Drogas psicoativas; Opinião pública; Moralidade; Autonomia moral; Survey.

\section{Abstract}

Drug use, public opinion and morality: motivation and arguments based on use

This article analyzes data from a national survey conducted in 2013, representative of the Brazilian population sixteen years and older, that looked at perceptions, practices and opinions pertaining to the use of psychoactive drugs in Brazil. It describes the behavior of different sociodemographic groups related to the consumption of alcohol, tobacco and illicit drugs and relates their behavior to an attitudinal scale built as a synthesis of eight variables of opinion on the consumption and politics of current illegal drugs. The article presents a multinomial logistic regression used to identify predictor variables of two positions that seem at first contradictory as far as dissonance between declared behavior and manifested attitude. One position being prohibitionist users of illicit drugs - supporters of present drug laws that criminalize consumption and prioritize a focus on the problem as being a question of public security - and the other being non-prohibitionists who do not use illicit drugs. This article analyzes these positions through the lens of Jean Piaget and Lawrence Kolhberg's constructivist psychosocial theory on morality and exposes the potential of these perspective to look at the discussion on public policy in regards to the universal phenomenon of the consumption of psychoactive substances.

Keywords: Psychoactive drugs; Public opinion; Morality; Moral autonomy; Survey.

Texto recebido em 11/2/2017 e aprovado em 23/2/2017. DoI: 10.11606/0103-2070.ts.2017.1 26682.

gustavo Venturi é professor do Departamento de Sociologia da Faculdade de Filosofia, Letras e Ciências Humanas da Universidade de São Paulo. É coordenador-adjunto do Consórcio de Informações Sociais (CIS, fruto de convênio USP/Anpocs) e tutor do Programa de Educação Tutorial (PET) do MEC nas ciências sociais da USP. É também pesquisador do Núcleo de Estudos para Prevenção da Aids (Nepaids- UsP), do Centro de Estudos de Opinião Pública (Cesop-Unicamp) e do grupo de pesquisa "Opinião pública: marketing político e comportamento eleitoral” (CNPq-UFMG).E-mail: gventuri@uol.com.br. 
